\title{
Interactive Learning Media Based on Augmented Reality and Active Learning Strategy in Primary School in the New Normal Era
}

\author{
Andika Adinanda Siswoyo*, Ade Cintya Pritasari, Rika Mellyaning Khoiriya \\ Elementary Teacher Education Program \\ Universitas Trunojoyo Madura \\ Madura, Indonesia \\ *andika.siswoyo@trunojoyo.ac.id, cintya@trunojoyo.ac.id,rikamel@trunojoyo.ac.id
}

\begin{abstract}
The aims of this Research is developing interactive learning media theme a Rotation and Earth Revolution Leaning Media Based on Augmented Reality valid, practical and effective. This development research uses the ADDIE development model. The results the research show that the average validity percentage of learning media by $88.70 \%$ in the category is very valid. The effectiveness of learning media is measured by classical completeness in small group trials which obtained $100 \%$ in the complete category so it can be concluded that learning media Rotation and the Earth Revolution Based on Augmented Reality and active learning strategy is effectively used in learning. The practical of learning media is measured by the percentage of students' responses in the small group trial of $94.58 \%$ with a very practically category. Therefore, it can be summed up that the Rotation and Earth Revolution Leaning Media Based On Augmented Reality are valid, practical and effective to use in Theme 8 Subtema 1 of rotation material and earth revolution grade VI in Elementary in primary school learning in the new normal era.
\end{abstract}

\section{Keywords - interactive learning media, augmented reality}

\section{INTRODUCTION}

Education aims, among other things, to improve the quality of human resources to make them more qualified [1]. Education is a conscious and planned effort to create an atmosphere of learning and the learning process so that students actively develop their potential to have religious spiritual strength, self-control, personality, intelligence, noble character, and the skills they need. The attainment of educational goals is influenced by several factors, among others, educators, students, the environment, learning devices and all facilities in the form of infrastructure and learning media [2]. Based on this role, teachers are required to always be sensitive and responsive to the times.

Based on these demands, teachers need learning aids in the form of more innovative learning media so that they can provide convenience in creating a more attractive, effective and efficient learning atmosphere. Learning media is important to present in learning because learning media provides many benefits besides facilitating the delivery of material, it also attracts students' attention so that they are motivated to learn. So learning media can attract interest, attention, motivate and stimulate student learning activities and can affect students' psychology Arsyad [3]. In this modern era, where science and technology is developing very rapidly, it has an influence on the creation of learning media that is more effective and efficient. Learning media are developing so rapidly and in a variety of ways, such as power points, videos, games, animation and flash applications. Technology-based learning media provide a more interesting, interactive and innovative way of learning, so that students can become enthusiastic in learning these materials [4].

Active learning strategy is a comprehensive collection of learning strategies. Active learning includes a variety of ways to keep students active from the start through activities that build group work and in a short time get them to think about the subject matter. Through augmented reality interactive learning media, emphasizing students to be more active in learning so that active learning strategies are relevant to be used for learning in elementary school [5]. So that the active learning process can run well, educators are required to use and mastering active learning strategies. An active learning strategy is needed because students have a way of learning different. There are those who enjoy learning by reading. There are also discussions happy with the hands-on way of practice. This is what often referred to as learning styles or learning style. Besides, the use of strategy active learning for educators is very help or facilitate in teaching.

Active Learning Strategy is a learning strategy designed to make students active in the teaching and learning process, while activeness can be interpreted from two aspects, namely in terms of students which means that activity is a process of activities carried out by students in the context of learning [6]. These activities can be physical, mental, or both. There are also those who place greater emphasis on mental activity, although 
to achieve this goal requires direct involvement in a variety of physical activities.

Based on the results of observations and interviews in the field, especially in primary schools in Madura, the ability of student learning activities during the pandemic was very low. Students have difficulty understanding online learning material, the absence of relevant learning media used for learning in the new normal period. Teachers cannot do offline learning, due to the adaptation period for new habits. So it really needs a specific interactive learning media based on augmented reality, assisted by active learning strategies.

Learning media innovation is needed to provide new experiences student learning and to be able to provide a concrete picture of a material. As an alternative to problem solving, it is necessary to develop interactive learning media for earth rotation and revolution based on augmented reality with the help of active learning strategies.

\section{MethodS}

This research is a Research and Development (R\&D) development research. Research and development functions to validate and develop a product [7]. Research and development carried out is to produce learning media for earth rotation and revolution based on augmented reality. Reiser and Molenda suggest 5 stages in the ADDIE development model, namely: (1) analysis, (2) design, (3) development, (4) implementation, (5) evaluation. The subjects of this study were sixth grade students of SDN in the Kamal Madura region, with heterogeneous characteristics of gender, academic ability, and culture.

In this study, there is a limit to the ADDIE development stages, namely in the implementation stage the developer limits the number of target trial subjects to only 20 students and the target trial subjects are students who are around the developer house and the developer only conducts individual trials and small group trials. The developer does not continue with target trials until the large group trial stage. These limitations are given because this research was conducted during the Covid-19 pandemic. The first stage in the development of interactive media augmented reality with an active learning strategy is to conduct analysis. This analysis stage aims to analyze initial needs as a basis for developing learning media. The needs analysis carried out include analysis of subjects and learning objectives, analysis of characteristics.

The second stage is the design activity which includes designing the product to be developed in accordance with the data obtained at the analysis stage. The design of the media that will be made includes the design of augmented reality applications and the design of the stages of active learning strategies. The third stage is development, where the product design has been made and is continued at the stage of making the product until it takes the form of augmented reality-based rotational learning media and earth revolution that is ready to be implemented, as well as a draft of the active learning strategy stages. The fourth stage of implementation is after the augmented reality-based rotational and earth revolution media have been developed, then apply learning media to expert trials and target trials to obtain an assessment of the product being developed which is seen in terms of validity, practicality, and effectiveness. And the last, the fifth stage is conducting an evaluation which includes a formative evaluation and a summative evaluation. Formative evaluation is a form of evaluation that is applied with the aim of improving product quality.

The data collection techniques used were (1) the interview was a data collection tool with an oral question and answer process to data sources; (2) Observation, is done to obtain information through direct observation of the object research; (3) Questionnaires, conducted with the aim of obtaining or collecting data by giving a set of questions or written statements to respondents to be answered; (4) Learning outcomes test, is used to determine the level of achievement and understanding of a person after learning something

\section{RESULTS AND DISCUSSION}

\section{A. Results}

The results of the study show that developed of development of interactive augmented reality learning media oriented active learning strategies valid, practical, and effectively used in primary schools.

The validity of Augmented reality interactive learning media is obtained from the validation results of each expert. The validation of learning media experts obtained a percentage of $80.68 \%$, the validation of learning designs $91.66 \%$ and the validation of learning materials $93.75 \%$. The results of the combined average validation calculation from 3 experts obtained a percentage of $88.70 \%$ with a very valid category. The results of the analysis will be presented as follows.

TABLE I. THE VALIDITY OF LEARNING MEDIA

\begin{tabular}{|l|l|l|}
\hline No & Validation Criteria & Percentage \\
\hline 1 & Expert of Instructional Media & $80,68 \%$ \\
\hline 2 & Expert of Learning Design & $91,66 \%$ \\
\hline 3 & Expert of Learning Material & $93,75 \%$ \\
\hline
\end{tabular}

The level of validity of instructional media experts, learning design experts, is in the very valid category. This is very relevant to the learning design on active learning strategies that are very suitable, and augmented reality learning media that are very suitable for learning materials.

The effectiveness of learning media for rotation and earth revolution based on augmented reality can be seen from the classical learning completeness. The results of classical completeness of the student learning outcomes test in individual trials were $100 \%$ with the complete category. Based on the results of the percentage of the effectiveness of these trials, it can be concluded that the development of augmented reality-based earth rotation and revolution learning media is in the effective category for use in learning. 
The classical completeness results from student learning outcomes tests in small group trials were $80 \%$ with classical complete categories. So it can be concluded that the development of augmented reality interactive learning media, the rotation and revolution of the earth based on augmented reality is effective to use

\section{B. Discussion}

Augmented reality interactive learning media oriented to active learning strategies are easy to apply in elementary schools. This learning media is able to help students understand the concept of earth and moon rotation in grade VI students at SDN Kamal Madura Region. Interactive learning media can increasing student learning motivation.

The use of Augmented Reality media can stimulate the mindset of students in thinking critically about problems and events that exist in everyday life, because the nature of educational media is to help students in the learning process with the presence or absence of educators in the educational process, so that the use of educational media with augmented reality can directly provide learning wherever and whenever students want to carry out the learning process. As state by Mustakim [8] also suggest that he use of the media augmented education with reality can directly provide learning wherever and whenever the learner wants to implement the learning process. Learning Media AR can visualize abstract concepts for the understanding. This is in line with opinion Lia [9] AR Learning Media provides a more realistic interaction and is an advancement of a promising technology method that can motivate users to engage in a more active learning system.

\section{CONCLUSION}

The classical completeness results of the student learning outcomes test in small group trials were $100 \%$ with the classical complete category. So it can be concluded that the development of interactive augmented reality learning media based on active learning strategies is effective for use. Based on the results of the Small Group Trial, the practicality of interactive learning media based on augmented reality can be seen from the results of student response questionnaires. The results of the student response questionnaire on individual trials resulted in a percentage of $93.33 \%$. The percentage yield if converted is included in very practical criteria.

This augmented reality interactive learning media was tested on grade VI SDN students in the Kamal Madura area. For further dissemination, this augmented reality interactive learning media is effectively used in the new normal period, especially in class VI theme 8 students with earth rotation material. So that student teachers are able to learn actively through the use of existing learning media.

\section{REFERENCES}

[1] Nurchaili, "Pengaruh Media Pembelajaran Berbasis Teknologi Informasi dalam Proses Pembelajaran Kimia Terhadap Peningkatan Hasil Belajar Siswa," Jurnal Pendidikan dan Kebudayaan, vol. 16, no. 6, 2010.

[2] N. Suryani and A. Setiawan, Media Pembelajaran Inovatif dan Pengembangannya, Bandung: PT Remaja Rosdakarya Offset, 2018.

[3] A. Arsyad, Media Pembelajaran, Jakarta: PT Raja Grafindo Persada, 2014.

[4] Nurchaili, "Pengaruh Media Pembelajaran Berbasis Teknologi Informasi dalam Proses Pembelajaran Kimia Terhadap Peningkatan Hasil Belajar Siswa," Jurnal Pendidikan dan Kebudayaan, vol. 16, no. 6, 2010.

[5] N. Nurdyansyah and T. Fitriyani, Pengaruh Strategi Pembelajaran Aktif Terhadap Hasil Belajar Pada Madrasah Ibtidaiyah. Universitas Muhammadiyah Sidoarjo, 2018

[6] R. M. Felder and R. Brent, Teaching and Learning STEM: A Practical Guide, Ch.6.San Francisco: Jossey-Bass, 2016.

[7] Sugiono, Metode Penelitian Pendidikan: Pedekatan Kuantitatif, Kualitatif dan R\&D, Bandung: Alfabeta, 2017.

[8] Mustakim, "Pemanfaatan Augmented Reality Sebagai Media Pembelajaran,” Jurnal Pendidikan Teknologi dan Kejuruan, 2019.

[9] Kamilia, "Perkembangan Teknologi Augmented Reality Sebagai Media Pembelajaran Interaktif Pada Mata Kuliah Kimia Dasar,” Jurnal Istek: UINSGD, 2019 